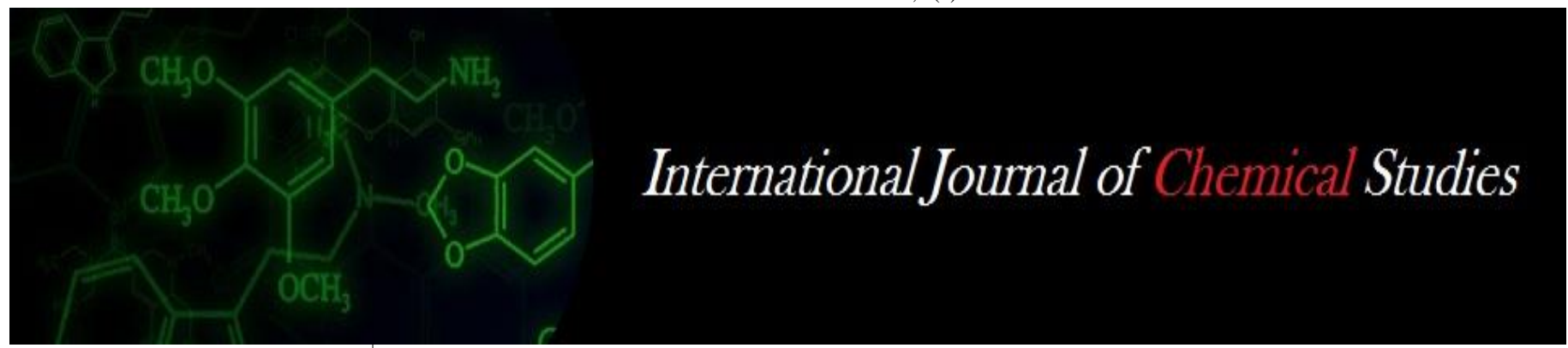

P-ISSN: 2349-8528

E-ISSN: 2321-4902

www.chemijournal.com

IJCS 2020; 8(5): 1902-1906

(C) 2020 IJCS

Received: 13-07-2020

Accepted: 15-08-2020

\section{Sanjit Pramanik}

Department of Soil and Water

Conservation, Bidhan Chandra

Krishi Viswavidyalaya,

Mohanpur Nadia, West Bengal, India

\section{R Ray}

Department of Soil and Water

Conservation, Bidhan Chandra

Krishi Viswavidyalaya,

Mohanpur Nadia, West Bengal, India

\section{SK Patra}

Department of Agricultural Chemistry and Soil Science, Bidhan Chandra Krishi Viswavidyalaya, Mohanpur Nadia, West Bengal, India

\section{Pinaki Acharjee}

Department of Agricultural Entomology, Bidhan Chandra Krishi Viswavidyalaya,

Mohanpur Nadia, West Bengal, India

\section{Malay Kanti Modak}

Dept. of Seed Science and

Technology, Institute of

Agricultural Science, Calcutta

University, Kolkata, West

Bengal, India
Corresponding Author: Sanjit Pramanik

Department of Soil and Water Conservation, Bidhan Chandra Krishi Viswavidyalaya,

Mohanpur Nadia, West Bengal, India

\section{Physicochemical properties of banana soils as influenced by drip-fertigation system}

\author{
Sanjit Pramanik, R Ray, SK Patra, Pinaki Acharjee and Malay Kanti \\ Modak
}

DOI: https://doi.org/10.22271/chemi.2020.v8.i5z.10580

\begin{abstract}
Field experiments were conducted on banana during 2008-2010 at the Mondouri Research Farm of AICRP on Tropical Fruits, Bidhan Chandra Krishi Viswavidyalaya, West Bengal encompassing Genetic plains of India with three levels of drip irrigation at 50,60 and 70\% of CPE and three levels of drip fertigation at 50, 60 and $80 \%$ of recommended NPK fertilizers with one conventional surface irrigation at IW/CPE 1.0laid in an augmented factorial complete block design having three replications to assess the changes of physicochemical properties of soil. The results of the study showed that irrespective of irrigation methods and levels of drip fertigation soil fertilization, the physicochemical parameters of soil such as $\mathrm{pH}, \mathrm{EC}$, organic carbon, water holding capacity, permeability, porosity and saturated hydraulic conductivity are consistently increasing with the increase depth of soil profile. However, drip fertigation system is found to be the best option in improving these soil health indices in comparison with the conventional surface irrigation and direct soil fertilization which is likely to increase the fruit yield, water and nutrient productivity of banana crop.
\end{abstract}

Keywords: Banana, drip irrigation, fertigation, physical and chemical properties of soils

\section{Introduction}

Banana is an important and leading fruit crop in India contributing 37\% of the total fruit production due to wide adaptability to varying soils and climatic conditions (Pawar and Dingre, 2013) ${ }^{[11]}$. In the lower Gangetic plains of West Bengal, the farmers generally follow the traditional surface method of irrigation in banana cultivation which produces moderate yield and renders excessive wastage of water and nutrients in deep percolation below the root zone, besides contributing to water logging, poor soil aeration and weed infestation (Veeraputhiram et al., 2005) ${ }^{[19]}$. Drip fertigation, on the other hand, is an efficient and economically viable irrigation technology in India and has proved its superiority over other methods of irrigation due to judicious application of water and nutrients in right time directly to the vicinity of crop root zone (Hebbar et al., 2004; Patel and Rajput, 2000) ${ }^{[3,10]}$. It also helps to increase the water and nutrient use efficiency by way of reducing the leaching and conveyance losses exclusively associated with conventional application (Solaimalai et al., 2005; Kumar et al., 2005; Gardenas et al., 2005; Raina et al., 2011) ${ }^{[15,6,1,12]}$. The mobility of water and nutrients to crop influences the fruit yield of banana which primarily depends on physicochemical properties of the soil. Very little work has been progressed on these aspects. Therefore, the present study was undertaken was to assess the impacts of drip fertigation vis-àvis conventional surface irrigation on the physicochemical properties of banana soils in the Gangetic plains of West Bengal, India.

\section{Materials and Methods}

Field experiments were conducted on banana cv. Martaman (AAB, Silk) during 2008-2010 at the Mondouri Research Farm of AICRP on Tropical Fruits, Bidhan Chandra Krishi Viswavidyalaya, West Bengal lying at $23.5^{\circ} \mathrm{N}$ latitude and $80^{\circ} \mathrm{E}$ longitudes with an elevation of $9.75 \mathrm{~m}$ above mean sea level. Soil is Genetic alluvium having salty clay in texture (Typic Haplaquept) with well drainage facility. The trial was laid out in an augmented factorial complete block design having three replications with ten treatments consisting of three drip irrigation schedules at $50\left(\mathrm{I}_{1}\right), 60\left(\mathrm{I}_{2}\right)$ and $70\left(\mathrm{I}_{3}\right) \%$ of cumulative pan evaporation $(\mathrm{CPE})$ and 
three fertigation schedules at $50\left(\mathrm{~F}_{1}\right), 60\left(\mathrm{~F}_{2}\right)$ and $80\left(\mathrm{~F}_{3}\right) \%$ of recommended NPK fertilizers through drip irrigation with one surface irrigation at IW/CPE 1.0 as standard check. A separate lateral line $(12 \mathrm{~mm})$ was laid for each treatment. Two drippers in each plant with a discharge rate of $1.8 \mathrm{lph}$ were provided on either side of plant at a distance of $30 \mathrm{~cm}$. The operating pressure of drip system was $1.2 \mathrm{kgcm}^{-2}$.Water requirement (WR) was computed based on pan evaporation, pan factor and crop co-efficient. The irrigation frequency by drip system was once in every 3 days in summer and 5 days in winter based on 50, 60 and $70 \%$ of evaporation replenishment. In surface method, irrigation water was applied at $100 \%$ of IW/CPE in 30 splits scheduled at 7-10 day interval with $50 \mathrm{~mm}$ depth per irrigation in check basin. The recommended dose of $\mathrm{N}, \mathrm{P}$ and $\mathrm{K}$ fertilizer was 250, 50 and $300 \mathrm{~g} \mathrm{plant}^{-1}$ year $^{-1}$ applied through urea $(46 \% \mathrm{~N})$, phosphoric acid $(31.68 \% \mathrm{P})$ and muriate of potash $\left(60 \% \quad \mathrm{~K}_{2} \mathrm{O}\right)$, respectively. Solid and liquid fertilizers as per schedules dissolved in an overhead tank connected to a bore well delivering good quality irrigation water controlled through a valve. This fertilizer-water mixture was injected into the drip system through a fertilizer injector at 3-5 day interval starting from 45 days after planting to 210 days. The concentration of nutrient solution passing through irrigation water was around 1.1 to $1.7 \%$. Drip fertigation was scheduled in 30 splits each commencing from $9^{\text {th }}$ to $38^{\text {th }}$ week for plant and ratoon crop. In surface method of irrigation, 100\% recommended dose of NPK fertilizers were applied in soil in 4 splits at 2, 5, 7 and 9 months after planting of plant and ratoon crop. The initial physicochemical characteristics of the soil are presented in Table 1. The treatment-wise soil samples were collected separately at a depth of $0-15,15-30,30-45$ and $45-60 \mathrm{~cm}$ layer before planting and harvesting of both plant and ratoon crop under surface irrigation plus soil fertilization and drip fertigation and analyzed for $\mathrm{pH}, \mathrm{EC}$, organic carbon, water holding capacity, porosity, permeability and saturated hydraulic conductivity of soils using the standard methods (Jackson, 1973) ${ }^{[4]}$. The data were subjected to statistical analysis such as analysis of variance using software like MS excel and SPSS 12.0 version. Statistical significance between means of individual treatments was assessed using Fisher's least significant difference (LSD) at $P<0.05$ level.

\section{Results and discussion \\ pH}

Soil $\mathrm{pH}$, irrespective of methods of irrigation and levels of fertilizer application, progressively decreased in varying magnitudes with increase in soil depth in drip as well as surface irrigated plots in both years (Table 2). The decrease in soil $\mathrm{pH}$ at the bottom layers is presumed that some amounts of nitrogenous and phosphatic fertilizers applied through drip or surface irrigation are leached from surface layer and accumulated in the layers underneath (Teixeira et al., 2007) [18], which in effect causes acidification due to phosphoric acid (Mohammad et al., 2004) ${ }^{[8]}$ and nitrogenous fertilizer on microbial decomposition (Hauter and Mengel, 1988; Parchomchuck et al., 1993) [2, 9]. However, drip irrigation at $60 \%$ of CPE or drip fertigation at $60 \%$ of recommended NPK fertilizers, on an average, recorded the higher $\mathrm{pH}$ values as compared to other drip irrigation and fertigation schedules (Table 4). The interaction between drip irrigation and fertigation on soil $\mathrm{pH}$ was significant which indicates that both irrigation and fertigation have a positive impact in changing the soil $\mathrm{pH}$. Drip irrigation as a whole was found to show relatively a higher $\mathrm{pH}$ value than in conventional surface irrigation (Tables 2 and 4).

\section{Electrical conductivity}

The electrical conductivity of soil regardless of methods of irrigation and fertilization significantly and consistently decreased with increase in soil depth in drip and surface irrigated plots in both years (Table 2). There was an improvement of EC values in surface layer when compared with initial soil value, possibly due to the addition of soluble materials through fertilizers. Drip irrigation at $60 \%$ of $\mathrm{CPE}$ recorded a relatively higher value than the initial soil value, while the levels of drip fertigation did not show a conspicuous change in EC values, rather it virtually remained unchanged (Table 4). It is postulated that application of higher amount of $\mathrm{K}$ accounted for more cation in solution resulting in higher electrical conductivity (Parchomchuck et al., 1993) ${ }^{[9]}$. The interaction between drip irrigation and fertigation on EC was significant, thereby indicating the role of drip fertigation in promoting the EC values. Relatively a higher value of EC was observed in drip irrigation than in surface irrigation (Tables 2 and 4).

\section{Organic carbon}

Irrespective of methods of irrigation and fertilization, soil organic carbon content decreased progressively and significantly with concomitant increase in soil depth in drip and surface irrigated plots in both years similar to that of soil $\mathrm{pH}$ and EC (Table 2). A little improvement of soil organic carbon was observed in all soil layers as compared with initial value, the more so in surface layer than in subsurface layers. On the contrary, application of drip irrigation or drip fertigation at incremental levels significantly increased the soil organic carbon, although in varying magnitudes (Table 4). The higher level of drip irrigation at $70 \%$ of CPE or of drip fertigation at $80 \%$ of recommended NPK fertilizers recorded the higher value of organic carbon. The increasing availability of $\mathrm{N}, \mathrm{P}$ and $\mathrm{K}$ in soil with congenial soil moisture regime as a result of drip fertigation might have increased the soil microbial activity leading to increased soil organic carbon (Salvin, 1999; Kavino et al.,2004) ${ }^{[14,5]}$. The interaction between drip irrigation and drip fertigation on soil organic carbon content was non-significant in both years. However, the drip irrigation as a whole showed a marginally higher value of soil organic carbon than in surface irrigation (Tables 2 and 4).

\section{Water holding capacity}

The stepwise significant decrease of water holding capacity down the layers of the soil profile, irrespective of methods of irrigation and fertilization, followed more or less the same trend as in soil pH, EC and organic C (Table 3). The effects of incremental levels of drip irrigation or fertigation in increasing the WHC of soil were significant similar to that of other soil parameters (Table 5). This may be attributable to profuse root biomass production owing to drip irrigation cum drip-fertilizer application as compared to conventional method of irrigation and direct fertilizer application in soil (Srinivas, 1997; Reddy et al., 2002) [16, 13] and their subsequent accumulation indifferent soil layers after decomposition. These results are in agreement with the findings of Swarup and Wanjari (2000) ${ }^{[17]}$. The interaction between drip irrigation and drip fertigation on soil water holding capacity was non-significant in both years. In comparison to conventional surface irrigation, soil water 
holding capacity was slightly higher in drip irrigation, although the difference was non-significant (Tables 3 and 5).

\section{Soil permeability}

The progressive decrease of soil permeability down the layers of the soil profile, irrespective of methods of irrigation and fertilization, closely followed the same trend as in other soil parameters (Table 3). The administration of incremental drip irrigation or fertigation significantly increased the soil permeability (Table 5) and the values were slightly higher than the initial soil value with some deviations. Higher production of soil organic carbon down the soil layers owing to drip irrigation as well as drip fertigation resulted in higher soil porosity in the layers underneath as was observed in the study leading to the increased soil permeability (Reddy et al., 2002) ${ }^{[13]}$. The interaction between drip irrigation and drip fertigation on soil permeability was significant in both years. The soil permeability was significantly higher in drip irrigation than in conventional surface irrigation (Tables 3 and 5).

\section{Saturated hydraulic conductivity}

The saturated hydraulic conductivity of soil, in general, consistently and significantly decreased with increasing depth of soil profile in drip and surface irrigated plots during first and second year (Table 3). The same finding has been reported by Mahendran and Mathan (1994) ${ }^{[7]}$. The increasing level of drip irrigation from 50 to $60 \%$ of $\mathrm{CPE}$ recorded the significant increase in saturated hydraulic conductivity of soil; thereafter it remained unchanged with further increase in the level of drip irrigation at $70 \%$ of CPE (Table 5). Similarly, the drip fertigation at $60 \%$ of recommended NPK fertilizers documented maximum saturated hydraulic conductivity, which was declined significantly with increase in fertigation level at $80 \%$ of recommended NPK fertilizers. The increased saturated hydraulic conductivity with increasing doses of NPK was observed by Swarup and Wanjari (2000) ${ }^{[17]}$. The interaction between irrigation and drip fertigation on saturated hydraulic conductivity of soil was significant in both the years. It was observed that drip irrigation as a whole performed better in promoting saturated hydraulic conductivity of soil than that of surface irrigation.

Table 1: Physical and chemical characteristics of the experimental soil.

\begin{tabular}{|c|c|c|c|c|c|c|c|c|}
\hline $\begin{array}{l}\text { Soil depth } \\
\text { (cm) }\end{array}$ & \begin{tabular}{|l|l|l|} 
Sand & Silt & Clay \\
$(\%)$ & $(\%)$ & $(\%)$ \\
\end{tabular} & $\begin{array}{l}\text { Bulk density } \\
\left(\mathbf{M g} / \mathrm{m}^{3}\right)\end{array}$ & $\begin{array}{l}\text { Water holding } \\
\text { capacity }(\%)\end{array}$ & $\begin{array}{c}\text { Soil permeability } \\
\left(10^{-6} \mathrm{MS}^{-1}\right)\end{array}$ & $\begin{array}{c}\text { Saturated hydraulic } \\
\text { conductivity }\left(\mathbf{1 0}^{-6} \mathrm{MS}^{-1}\right)\end{array}$ & $\begin{array}{c}\mathbf{p}^{\mathbf{H}} \\
(\mathbf{1}: 2)\end{array}$ & $\begin{array}{c}\text { EC } \\
\left(\mathbf{d S m}^{-1}\right)\end{array}$ & $\begin{array}{c}\text { Organic } \\
\text { carbon }(\%)\end{array}$ \\
\hline $0-15$ & 10.140 .049 .9 & 1.27 & 50.25 & 2.74 & 1.76 & 6.46 & 0.10 & 0.45 \\
\hline $15-30$ & \begin{tabular}{|l|l|l|}
10.5 & 41.3 & 48.2 \\
\end{tabular} & 1.31 & 49.06 & 2.18 & 1.35 & 6.38 & 0.08 & 0.39 \\
\hline $30-45$ & \begin{tabular}{|l|l|l|}
12.2 & 42.1 & 45.7 \\
\end{tabular} & 1.42 & 48.21 & 1.72 & 0.97 & 6.28 & 0.09 & 0.36 \\
\hline $45-60$ & \begin{tabular}{|l|l|l|}
14.3 & 40.8 & 44.9 \\
\end{tabular} & 1.46 & 46.83 & 1.32 & 0.64 & 6.30 & 0.07 & 0.31 \\
\hline
\end{tabular}

Table 2: Effect of different levels of drip and surface irrigation on $\mathrm{pH}$, electrical conductivity and organic carbon content of soils under banana plantation.

\begin{tabular}{|c|c|c|c|c|c|c|c|c|c|}
\hline \multirow{2}{*}{ Depth (cm) } & \multicolumn{3}{|c|}{ pH } & \multicolumn{3}{|c|}{$E C\left(d S^{-1}\right)$} & \multicolumn{3}{|c|}{ Organic carbon (\%) } \\
\hline & Plant & Ratoon & Mean & Plant & Ratoon & Mean & Plant & Ratoon & Mean \\
\hline \multicolumn{10}{|c|}{ Drip irrigation } \\
\hline $0-15$ & 6.57 & 6.41 & 6.49 & 0.15 & 0.18 & 0.17 & 0.49 & 0.48 & 0.49 \\
\hline $15-30$ & 6.50 & 6.36 & 6.43 & 0.12 & 0.15 & 0.14 & 0.42 & 0.44 & 0.43 \\
\hline $30-45$ & 6.44 & 6.34 & 6.39 & 0.09 & 0.12 & 0.11 & 0.36 & 0.37 & 0.37 \\
\hline $45-60$ & 6.39 & 6.18 & 6.28 & 0.08 & 0.08 & 0.08 & 0.29 & 0.33 & 0.31 \\
\hline $\mathrm{CD}(0.05)$ & 0.04 & $\mathrm{NS}$ & 0.11 & 0.01 & 0.01 & 0.01 & 0.02 & 0.02 & 0.01 \\
\hline \multicolumn{10}{|c|}{ Surface irrigation } \\
\hline $0-15$ & 6.51 & 6.35 & 6.43 & 0.12 & 0.14 & 0.13 & 0.48 & 0.46 & 0.47 \\
\hline $15-30$ & 6.46 & 6.32 & 6.39 & 0.10 & 0.13 & 0.12 & 0.40 & 0.42 & 0.41 \\
\hline $30-45$ & 6.38 & 6.24 & 6.31 & 0.11 & 0.10 & 0.11 & 0.35 & 0.39 & 0.37 \\
\hline $45-60$ & 6.34 & 6.31 & 6.32 & 0.10 & 0.09 & 0.10 & 0.28 & 0.32 & 0.30 \\
\hline $\mathrm{CD}(0.05)$ & 0.03 & NS & 0.09 & 0.01 & 0.01 & 0.01 & 0.03 & 0.02 & 0.01 \\
\hline Drip & 6.48 & 6.32 & 6.40 & 0.11 & 0.14 & 0.13 & 0.39 & 0.40 & 0.40 \\
\hline Surface & 6.42 & 6.31 & 6.36 & 0.10 & 0.11 & 0.11 & 0.37 & 0.39 & 0.38 \\
\hline $\mathrm{CD}(0.05)$ & 0.05 & NS & 0.13 & 0.01 & 0.01 & 0.01 & NS & 0.02 & 0.02 \\
\hline
\end{tabular}

NS: Not significant

Table 3: Effect of different levels of drip and surface irrigation on soil water holding capacity, permeability and saturated hydraulic conductivity of soil under banana plantation.

\begin{tabular}{|c|c|c|c|c|c|c|c|c|c|c|c|c|}
\hline \multirow{2}{*}{$\begin{array}{c}\text { Depth } \\
\text { (cm) }\end{array}$} & \multicolumn{3}{|c|}{ Water holding capacity (\%) } & \multicolumn{3}{|c|}{$\begin{array}{c}\text { Soil permeability } \\
\left(10^{-6} \mathrm{MS}^{-1}\right)\end{array}$} & \multicolumn{3}{|c|}{$\begin{array}{c}\text { Porosity } \\
(\%)\end{array}$} & \multicolumn{3}{|c|}{$\begin{array}{c}\text { Saturated hydraulic } \\
\text { conductivity }\left(\mathbf{1 0}^{-6} \mathrm{MS}^{-1}\right)\end{array}$} \\
\hline & Plant & ato & Mean & Plant & Ratoon & Mean & Plant & Ratoon & Mean & Plant & Ratoon & Mean \\
\hline \multicolumn{13}{|c|}{ Drip irrigation } \\
\hline $0-15$ & .26 & 50.2 & 50.74 & 3.20 & 3.34 & 3.27 & 50.70 & 50.38 & 50.54 & 2.13 & 2.18 & 2.15 \\
\hline $15-30$ & & & 70 & 53 & & 2.56 & 48.54 & 48.74 & 48.64 & 1.40 & 5 & 43 \\
\hline $30-45$ & 30 & 0 & 48.60 & 1.96 & 2.03 & 1.99 & 46.91 & 46.87 & 46.89 & 1.03 & 7 & 1.05 \\
\hline $45-60$ & .18 & & 47.34 & 1.57 & 1.62 & 1.59 & 45.28 & 45.26 & 45.27 & 0.81 & 5 & 0.83 \\
\hline $\mathrm{CD}(0.05$ & 004 & & & 0.03 & 0.03 & 0.03 & 0.47 & 0.48 & 0.31 & 0.03 & 2 & 0.02 \\
\hline \multicolumn{13}{|c|}{ Surface irrigation } \\
\hline $0-15$ & 49.21 & 50.78 & 50.00 & 2.85 & 3.02 & 2.94 & \begin{tabular}{|l|}
49.00 \\
\end{tabular} & 48.18 & \begin{tabular}{|l|}
48.59 \\
\end{tabular} & 1.88 & 2.00 & 1.94 \\
\hline $15-30$ & 48.09 & 47.98 & 48.03 & 2.31 & 2.41 & 2.36 & 48.05 & 47.58 & 47.81 & 1.34 & 1.35 & 1.34 \\
\hline $30-45$ & 48.00 & 46.87 & 47.44 & 1.74 & 1.85 & 1.80 & 46.51 & 46.51 & 46.52 & 0.96 & 0.98 & 0.97 \\
\hline $45-60$ & 46.79 & 45.61 & 46.20 & 1.43 & 1.47 & 1.45 & 44.34 & 45.38 & 44.86 & 0.67 & 0.73 & 0.70 \\
\hline
\end{tabular}




\begin{tabular}{|c|c|c|c|c|c|c|c|c|c|c|c|c|}
\hline $\mathrm{CD}(0.05)$ & 0.12 & 0.14 & 0.08 & 0.04 & 0.05 & 0.02 & 0.32 & 0.35 & 0.22 & 0.04 & 0.02 & 0.02 \\
\hline Drip & 49.84 & 48.35 & 49.10 & 2.31 & 2.39 & 2.35 & 47.85 & 47.81 & 47.83 & 1.34 & 1.39 & 1.36 \\
\hline Surface & 48.02 & 47.81 & 47.92 & 2.09 & 2.19 & 2.14 & 46.97 & 46.86 & 46.94 & 1.21 & 1.26 & 1.24 \\
\hline $\mathrm{CD}(0.05)$ & 0.64 & NS & 0.63 & 0.04 & 0.04 & 0.03 & 0.56 & NS & 0.37 & 0.03 & 0.03 & 0.03 \\
\hline
\end{tabular}

NS: Not significant

Table 4: Effect of different levels of drip fertigation on $\mathrm{pH}$, electrical conductivity and organic carbon content of soil under banana plantation.

\begin{tabular}{|c|c|c|c|c|c|c|c|c|c|}
\hline \multirow[t]{2}{*}{ Treatment } & \multicolumn{3}{|c|}{ pH } & \multicolumn{3}{|c|}{$\mathrm{EC}\left(\mathrm{dSm}^{-1}\right)$} & \multicolumn{3}{|c|}{ Organic carbon (\%) } \\
\hline & Plant & Ratoon & Mean & Plant & Ratoon & Mean & Plant & Ratoon & Mean \\
\hline \multicolumn{10}{|l|}{ Irrigation } \\
\hline $\mathrm{I}_{1}$ & 6.46 & 6.28 & 6.37 & 0.08 & 0.10 & 0.09 & 0.37 & 0.35 & 0.36 \\
\hline $\mathrm{I}_{2}$ & 6.47 & 6.38 & 6.43 & 0.11 & 0.11 & 0.11 & 0.40 & 0.38 & 0.39 \\
\hline $\mathrm{I}_{3}$ & 6.50 & 6.31 & 6.40 & 0.11 & 0.12 & 0.12 & 0.42 & 0.39 & 0.41 \\
\hline $\mathrm{CD}(0.05)$ & NS & NS & NS & 0.01 & 0.01 & 0.01 & 0.01 & 0.02 & 0.01 \\
\hline \multicolumn{10}{|l|}{ Fertilizer } \\
\hline $\mathrm{F}_{1}$ & 6.39 & 6.28 & 6.33 & 0.10 & 0.11 & 0.11 & 0.36 & 0.34 & 0.35 \\
\hline $\mathrm{F}_{2}$ & 6.54 & 6.43 & 6.49 & 0.11 & 0.11 & 0.11 & 0.40 & 0.38 & 0.39 \\
\hline $\mathrm{F}_{3}$ & 6.50 & 6.26 & 6.38 & 0.11 & 0.12 & 0.12 & 0.43 & 0.40 & 0.42 \\
\hline $\mathrm{CD}(0.05)$ & 0.04 & NS & 0.10 & 0.01 & 0.01 & 0.01 & 0.01 & 0.02 & 0.01 \\
\hline \multicolumn{10}{|c|}{ Irrigation x Fertilizer } \\
\hline $\mathrm{I}_{1} \mathrm{~F}_{1}$ & 6.29 & 6.08 & 6.19 & 0.08 & 0.10 & 0.09 & 0.34 & 0.31 & 0.33 \\
\hline $\mathrm{I}_{1} \mathrm{~F}_{2}$ & 6.53 & 6.42 & 6.47 & 0.10 & 0.11 & 0.11 & 0.37 & 0.35 & 0.36 \\
\hline $\mathrm{I}_{1} \mathrm{~F}_{3}$ & 6.55 & 6.34 & 6.45 & 0.11 & 0.12 & 0.12 & 0.39 & 0.40 & 0.40 \\
\hline $\mathrm{I}_{2} \mathrm{~F}_{1}$ & 6.43 & 6.28 & 6.36 & 0.09 & 0.11 & 0.10 & 0.36 & 0.34 & 0.35 \\
\hline $\mathrm{I}_{2} \mathrm{~F}_{2}$ & 6.56 & 6.43 & 6.50 & 0.11 & 0.11 & 0.11 & 0.40 & 0.40 & 0.40 \\
\hline $\mathrm{I}_{2} \mathrm{~F}_{3}$ & 6.42 & 6.42 & 6.42 & 0.12 & 0.13 & 0.13 & 0.43 & 0.39 & 0.41 \\
\hline $\mathrm{I}_{3} \mathrm{~F}_{1}$ & 6.43 & 6.48 & 6.46 & 0.11 & 0.11 & 0.11 & 0.36 & 0.37 & 0.37 \\
\hline $\mathrm{I}_{3} \mathrm{~F}_{2}$ & 6.53 & 6.43 & 6.48 & 0.11 & 0.12 & 0.12 & 0.43 & 0.40 & 0.41 \\
\hline $\mathrm{I}_{3} \mathrm{~F}_{3}$ & 6.53 & 6.01 & 6.27 & 0.13 & 0.14 & 0.14 & 0.46 & 0.42 & 0.44 \\
\hline $\mathrm{CD}(0.05)$ & 0.07 & 0.34 & 0.17 & 0.01 & 0.01 & 0.01 & NS & NS & NS \\
\hline Drip & 6.48 & 6.32 & 6.40 & 0.11 & 0.14 & 0.13 & 0.39 & 0.40 & 0.39 \\
\hline Surface & 6.42 & 6.31 & 6.36 & 0.10 & 0.11 & 0.11 & 0.37 & 0.39 & 0.38 \\
\hline $\mathrm{CD}(0.05)$ & 0.05 & NS & 0.13 & 0.01 & 0.01 & 0.01 & NS & 0.02 & 0.01 \\
\hline
\end{tabular}

NS: Not significant

Table 5.Effect of different levels of drip fertigation on soil water holding capacity, permeability and saturated hydraulic conductivity of soil under banana plantation.

\begin{tabular}{|c|c|c|c|c|c|c|c|c|c|c|c|c|}
\hline \multirow[t]{2}{*}{ Treatment } & \multicolumn{3}{|c|}{$\begin{array}{c}\text { Water holding capacity } \\
(\%)\end{array}$} & \multicolumn{3}{|c|}{$\begin{array}{c}\text { Soil permeability } \\
\left(10^{-6} \mathrm{MS}^{-1}\right)\end{array}$} & \multicolumn{3}{|c|}{$\begin{array}{c}\text { Porosity } \\
(\%)\end{array}$} & \multicolumn{3}{|c|}{$\begin{array}{c}\text { Saturated hydraulic } \\
\text { conductivity }\left(10^{-6} \mathrm{MS}^{-1}\right)\end{array}$} \\
\hline & Plant & Ratoon & Mean & Plant & Ratoon & Mean & Plant & \begin{tabular}{|l|} 
Ratoon \\
\end{tabular} & Mean & Plant & Ratoon & Mean \\
\hline \multicolumn{13}{|c|}{ 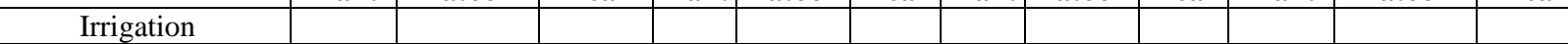 } \\
\hline $\mathrm{I}_{1}$ & 49.19 & 47.82 & 48.50 & 2.22 & 2.25 & 2.24 & \begin{tabular}{|l|}
47.02 \\
\end{tabular} & 47.89 & 47.45 & 1.24 & 1.28 & 1.26 \\
\hline $\mathrm{I}_{2}$ & 49.67 & 48.02 & 48.84 & 2.23 & 2.38 & 2.31 & 46.91 & 47.28 & 47.09 & 1.39 & 1.44 & 1.42 \\
\hline $\mathrm{I}_{3}$ & 50.67 & 49.22 & 49.94 & 2.49 & 2.54 & 2.52 & 47.49 & 47.81 & 47.65 & 1.39 & 1.44 & 1.42 \\
\hline $\mathrm{CD}(0.05)$ & 0.49 & 0.76 & 0.49 & 0.03 & 0.03 & 0.03 & 0.43 & 0.44 & 0.29 & 0.02 & 0.02 & 0.02 \\
\hline \multicolumn{13}{|l|}{ Fertilizer } \\
\hline$F_{1}$ & 49.37 & 47.69 & 48.53 & 2.26 & 2.33 & 2.30 & 47.82 & 47.09 & 47.46 & 1.30 & 1.34 & 1.32 \\
\hline $\mathrm{F}_{2}$ & 50.24 & 48.34 & 49.29 & 2.28 & 2.45 & 2.37 & \begin{tabular}{|l|}
48.07 \\
\end{tabular} & 47.75 & 47.91 & 1.39 & 1.43 & 1.41 \\
\hline $\mathrm{F}_{3}$ & 49.91 & 49.02 & 49.47 & 2.39 & 2.40 & 2.40 & 47.52 & 48.37 & 47.95 & 1.33 & 1.39 & 1.36 \\
\hline $\mathrm{CD}(0.05)$ & 0.49 & 0.76 & 0.49 & 0.03 & 0.03 & \begin{tabular}{|l|}
0.03 \\
\end{tabular} & 0.43 & 0.44 & 0.29 & 0.02 & 0.02 & 0.02 \\
\hline \multicolumn{13}{|c|}{ Irrigation $\mathrm{x}$ Fertilizer } \\
\hline $\mathrm{I}_{1} \mathrm{~F}_{1}$ & 48.87 & 46.98 & 47.92 & 2.12 & 2.19 & 2.15 & 47.81 & 46.49 & 47.15 & 1.10 & 1.16 & 1.13 \\
\hline $\mathrm{I}_{1} \mathrm{~F}_{2}$ & 49.27 & 48.16 & 48.71 & 2.16 & 2.28 & 2.22 & 47.97 & 48.47 & 48.22 & 1.34 & 1.33 & 1.34 \\
\hline $\mathrm{I}_{1} \mathrm{~F}_{3}$ & 49.42 & 48.31 & 48.87 & 2.38 & 2.30 & 2.34 & 47.90 & 48.73 & 48.31 & 1.29 & 1.35 & 1.32 \\
\hline $\mathrm{I}_{2} \mathrm{~F}_{1}$ & 48.96 & 47.00 & 47.98 & 2.18 & 2.24 & 2.21 & 48.07 & 47.17 & 47.62 & 1.33 & 1.36 & 1.34 \\
\hline $\mathrm{I}_{2} \mathrm{~F}_{2}$ & 50.20 & 48.45 & 49.33 & 2.25 & 2.50 & 2.38 & 48.09 & 47.90 & 48.00 & 1.45 & 1.50 & 1.47 \\
\hline $\mathrm{I}_{2} \mathrm{~F}_{3}$ & 49.85 & 48.60 & 49.22 & 2.26 & 2.41 & 2.33 & 47.57 & 48.28 & 47.92 & 1.41 & 1.45 & 1.43 \\
\hline $\mathrm{I}_{3} \mathrm{~F}_{1}$ & 50.29 & 49.10 & 49.69 & 2.49 & 2.56 & 2.52 & 47.59 & 47.62 & 47.61 & 1.48 & 1.50 & 1.49 \\
\hline $\mathrm{I}_{3} \mathrm{~F}_{2}$ & 51.24 & 48.40 & 49.82 & 2.45 & 2.56 & 2.50 & 48.14 & 47.33 & 47.74 & 1.40 & 1.45 & 1.42 \\
\hline $\mathrm{I}_{3} \mathrm{~F}_{3}$ & 50.47 & 50.16 & 50.31 & 2.54 & 2.50 & 2.52 & 47.10 & 48.11 & 47.61 & 1.29 & 1.38 & 1.33 \\
\hline $\mathrm{CD}(0.05)$ & $\mathrm{NS}$ & NS & NS & 0.05 & 0.05 & 0.05 & NS & 0.76 & 0.50 & 0.04 & 0.04 & 0.04 \\
\hline Drip & 49.84 & 48.35 & 49.10 & 2.31 & 2.39 & 2.35 & 47.85 & 47.81 & 47.83 & 1.34 & 1.39 & 1.36 \\
\hline Surface & 48.02 & 47.81 & 47.92 & 2.09 & 2.19 & 2.14 & 46.97 & 46.91 & 46.94 & 1.21 & 1.26 & 1.24 \\
\hline $\mathrm{CD}(0.05)$ & 0.64 & NS & 0.63 & \begin{tabular}{|l|}
0.04 \\
\end{tabular} & 0.04 & \begin{tabular}{|l|}
0.03 \\
\end{tabular} & 0.56 & NS & 0.37 & 0.03 & 0.03 & 0.03 \\
\hline
\end{tabular}

NS: Not significant 


\section{Conclusions}

Drip fertigation is found to be the best option in sustaining the physicochemical properties of soil by improving the $\mathrm{pH}, \mathrm{EC}$, organic carbon, water holding capacity, permeability, porosity and saturated hydraulic conductivity of soil in comparison with conventional surface irrigation and soil fertilization. The environment generated by drip fertigation is conducive for maintaining the optimum level of water and nutrients in soil which is likely to increase the fruit yield, water and nutrient productivity of banana crop.

\section{References}

1. Gardenas A, Hopmans JW, Hanson BR, Simunek J. Twodimensional modeling of nitrate leaching for different fertigation strategies under micro-irrigation. Agric. Water Mgmt. 2005; 74:219-42.

2. Hauter R, Mengel K. Measurements $\mathrm{pH}$ at the root surface of red clover (Trifolium pratense) in soils differing in proton buffer capacity. Biol. Fert. Soils, 1988; 5:295-98.

3. Hebbar SS, Ramachandrappa BK, Nanjappa HV, Prabhakar M. Studies on NPK drip fertigation in field grown tomato (Lycopersicon esculentum Mill.). European J Agron. 2004; 21:117-27.

4. Jackson ML. Soil chemical analysis, $2^{\text {nd }}$ Ed. Prentice Hall Ind. Pvt. Ltd., New Delhi, 1973, 111-82.

5. Kavino M, Kumar N, Soorianathasundarm K, Jayakumar P. Effect of fertigation on the growth and development of first ratoon crop $\left(\mathrm{R}_{1}\right)$ of banana cv. Robusta (AAA) under high density planting system. Indian J. Hort. 2004; 61:3941.

6. Kumar S, Sharma IP, Raina JN. Effect of levels and application methods of irrigation and mulch materials on strawberry production in North-West Himalayas. J Indian Soc. Soil Sci. 2005; 53:60-65.

7. Mahendran PP, Mathan KK. Morphological characteristics and clay content in major subgroups of Kamranjar district and its relation to saturated hydraulic conductivity. Madras Agric. J. 1994; 81:486-89.

8. Mohammad, Jamil Munir, Hammouri Ahmed, Ferdows Elnabi Abed. Phosphorus fertigation and preplant conventional soil application of drip irrigated summer squash. J of Agron. 2004; 3:162-69.

9. Parchomchuk P, Nielsen GH, Hogue EJ. Effect of drip fertigation of $\mathrm{NH}_{4}-\mathrm{N}$ and $\mathrm{P}$ on soil $\mathrm{pH}$ and cation leaching. Can. J Soil. Sci. 1993; 73:157.

10. Patel N, Rajput TBS. Effect of fertigation on growth and yield of onion. In: Micro Irrigation, CBIP Publication no. 2000; 282:451-54.

11. Pawar DD, Dingre SK. Influence of fertigation scheduling through drip on growth and yield of banana in western Maharashtra. Indian J Hort. 2013; 70:200-05.

12. Raina JN, Sharma T, Suman S. Effect of drip fertigation with different fertilizers on nutrient distribution in soil, leaf nutrient cand yield of apricot (Prunus armeniaca L.).J Indian Soc. Soil Sci. 2011; 59:268-77.

13. Reddy BMC, Srinivas K, Padma P, Raghupathi HB. Response of robusta banana to $\mathrm{N}$ and $\mathrm{K}$ fertigation. Indian J Hort. 2002; 59:342-48.

14. Salvin S. Drip irrigation studies in banana cv. Barjahaji (Musa AAA group, Cavendish sub-group), M. Sc (Agril) Thesis, Assam Agricultural University, Jorhat, 1999.

15. Solaimalai, A, Baskar M, Sadasakthi A, Subburamu K. Fertigation in high value crops - A review. Agric. Rev. $2005 ; 26: 1-13$.
16. Srinivas K. Growth, yield, and quality of banana in relation to N fertigation. Trop. Agric. 1997; 74:260-64.

17. Swarup A, Wanjari RH. In: Three decades of All India Coordinated Research Project on Long-Term fertilizer experiments to study changes in soil quality, crop productivity and sustainability, Indian Institute of Soil Science, Bhopal, 2000, 31-32.

18. Teixeira LAJ, Natale W, Bettiol Neto JE, Martins ALM. Nitrogen and potassium application on banana plant by fertirrigation and conventional fertilization - soil chemical properties. Rev. Brasileira de Frutic. 2007; 29:143-52.

19. Veeraputhiram R, Kandasamy OS, Singh SDS, Chinnusamy $\mathrm{C}$. Influence of drip irrigation and nitrogen fertigation on growth and yield of hybrid cotton. J Ecobiol. 2005; 17:329-35. 